\title{
INTERNATIONAL WELFARE COMPARISON USING GDP AND BETTER LIFE INDEX PARAMETERS
}

\author{
DOI: 10.17261/Pressacademia.2017.361 \\ JEFA-V.4-ISS.1-2017(1)-p.1-14
}

\section{Olcay Yilmaz}

Adnan Menderes University. Nazilli Faculty of Ecnomics and Admin.Sciences, Nazilli, Aydin, Turkey. olcy.ylmz@gmail.com

To cite this document

Yilmaz, O. (2017). International welfare comparison using GDP and better life index parameters. Journal of Economics, Finance and Accounting (JEFA), V.4, Iss.1, p.1-14.

Permemant link to this document: http://doi.org/10.17261/Pressacademia.2017.361

Copyright: Published by PressAcademia and limited licenced re-use rights only.

\begin{abstract}
Purpose- In this study, an international welfare comparison is made for OECD members together with selected thirty eight countries using purchasing power parity (PPP) based on GDP per capita and better life index (BLI) parameters which is prepared by OECD as an alternative to welfare measurement. The purpose of this study is to research relations between national income and human welfare that is generated according to BLI criteria's.

Methodology- For this study, 2016 year data is used. The reasons are: Latvia and South Africa countries are added in 2016 and 2016 year is the latest edition for BLI which is renewed itself year by year. In addition when BLI is compared with GDP, reasons of being preferred PPP numbers are: One of the variables of BLI which is income criteria and its indicators incomes and fortunes of households are calculated by PPP based; PPP gives opportunity to comparison of real good and services eliminating the differences of price level among countries; in calculation of PPP, economic factors such as currency fluctuations, interest rates and capital flows are not taken into account; rather than just National income, PPP based GDP per capita is more personal like BLI.

Findings- The result obtained from this study is that; when it examined carefully, countries with high national income per capita cannot score high in terms of BLI values. At first glance, it can be asserted that there is a strong positive relation between GDP per capita and BLI parameters by saying that countries like Norway, Switzerland and Sweden are at the top both in national income per capita and BLI based rankings; or countries like South Africa, Mexico, Brazil, Turkey are at the bottom both in national income per capita and BLI based rankings. However, if there was a strong positive relation between GDP per capita and BLI; Luxembourg, which is by far the best in national income per capita ranking, wouldn't be placed rank number twelve in average BLI values ranking. Similarly, New Zealand, which is placed rank number twenty in national income per capita ranking among thirty eight countries, wouldn't be placed rank number seven in average BLI values ranking. These tangible examples are not limited to a few countries. For example, Ireland, which ranks fourth in GDP per capita rankings, ranks sixteenth in average BLI values rankings; Denmark, which ranks twelfth in the national income per capita, ranks third in terms of average $B L I$ values rankings.

Conclusion- A country's high level of national income does not necessarily mean that it is at a level of contemporary civilization. If it is asked to evaluate a country in terms of welfare perspective; not just only monetary value of produced goods and services in that country shouldn't be taken into account but also factors such as education, justice, employment, security, environment and social connections should be taken into account from a wider perspective.
\end{abstract}

Keywords: Better Life Index, OECD, international welfare comparison. JEL Codes: 130, 132, 138 


\title{
1. INTRODUCTION
}

\author{
"The welfare of a nation can scarcely be inferred from \\ a measurement of national income" (Kuznets, 1934 \\ quoted Köhler and Chaves, 2003: 336)
}

Human welfare has numerous uses; however it does not have acceptable common definition on a universal scale. For example; Concepts such as quality of life, good living, living standards, life satisfaction, fulfillment of needs, human development, growth and development, wealth were used instead of human welfare without any discussion over time (McGillivray and Clarke, 2006: 3).

How difficult to define a human welfare that everyone is agreed, it is more difficult to do common measurement of human welfare (Conceição and Bandura, 2008: 2). Although Galileo Galilei who is known as the father of modern science said in the $17^{\text {th }}$ century, "Measure what is measurable, and make measurable what is not so." How people's overall happiness and life satisfaction (human welfare) can be measured? For example, while the definition of welfare for Einstein is, "one table, one chair, a bowl of fruit and violin, for Jane Austen "an adequate income", for Tolstoy "the link between man and nature" and for Albert Schweitzer "good health and a bad memory". There are some reasons to search for solutions. These are: Definition of human welfare is personal, possibilities of changing to even the next day and in general they do not give many clues what contributes to the better life (Bilicki, 2012).

The use of global GDP which is widely accepted measurement of economic development of the countries for more than half a century based on the Bretton Woods conference. In this conference, it is planned that international trade will create employment in all countries and this employment will provide revenue, enough food, housing, medical care and other facilities in order to increase welfare. (Costanza, Hart, Posner \& Talberth 2009: 5). Although Simon Kuznets who is the founder of modern GDP emphasized at the end of 1930 " GDP is not suitable for the measurement of economic growth of the countries, it is not a welfare measure, it is not a measure of how well we are all doing. It counts the things that we're buying and selling" (Thomson, 2016), the variables of improvement of living standards and GDP have been counted equal especially in US and Europe after II. World war (The Economist, 2016).

Kennedy said in his speech in 1968; "The Gross National Product does not allow for the health of our children, the quality of their education, or the joy of their play. It does not include the strength of our marriages or the honesty of our public officials. It measures neither our wit nor our courage, neither our wisdom nor our learning, neither our compassion nor our devotion to our country; it measures everything except that which makes life worthwhile" and he complained about the lack of new and equitable welfare measurement (CASSE, 2009: 1).

Even though GDP is preferred indicator that both macroeconomic policy requires the measurement of economic activities of countries and even in the short term in order to see what country economies did, economists and politicians are required to stop using GDP growth instead of the general welfare of society (Coyle, 2014). Indeed, changings occurring at living standards with globalization increased criticisms to GDP at the end of the $20^{\text {th }}$ century, in the early of $21^{\text {st }}$ century. Most fundamental criticisms to GDP are: GDP is not a suitable model to reflect the challenges of this period such as climate change, public health and the environment (Barroso, 2007: 10), except for growth; it does not include elements like health, environment, culture (Pöttering, 2007: 13), it can't distinguish between positive or negative effects that economic activities have welfare, war and natural disasters may cause the increase in GDP, it does not take into account non-economic factors which is possible to add in welfare, many policies which contribute to the welfare not adequately reflected in the growth, for example, when a low-carbon energy invested, while solutions may be required in terms of the environment and longterm sustainability, in this case may not be preferred in GDP for short-term economic growth (Almunia, 2007: 28), it does not take into account of the free-rider problem, it does not have any indicator of fairness in income distribution (Berès, 2007: 44).

The criticisms to GDP in measurement of welfare have caused to the emergence of many new approaches. The OECD revealed BLI which stops being a mere welfare measurement based on GDP in 2011. BLI has a huge importance with eleven separate criteria while combining objective and subjective data's and thanks to it; it is easier to obtain more concrete and comprehensive results. These eleven criteria's of BLI are in terms of material life conditions: housing, income, jobs and in terms of quality of life: social communication, education, environment, civic engagement and governance, health, personal well-being (life satisfaction), safety and work-life balance. BLI aims both obtaining and providing more detailed information by grouping these eleven main criteria by itself. For example, an education criteria is evaluated under three sub-headings in itself such as educational achievements, academic year and students skills. According to this index, Governments can see where they made mistakes from these eleven criteria and they can take a variety of precautions not only in terms of economy but also socio-economic, political and cultural.

Even in this period, many statesmen, politicians and economists ignored important elements of human welfare such as education, security, environment, justice, health etc., and they just used GDP numbers and they thought that a country 
grew up and developed by GDP. Parallel to this idea human welfare has also increased. If national income is accepted to be exactly same as welfare, then these countries which have high national income values will surely be at the top in the welfare rank. Is this really true? Can't other criteria really affect welfare? In this study, ignored criteria such as education, democracy, employment, security, environment, social relations, human rights and life satisfaction from the point of effect of national income on welfare, are evaluated from a broad perspective by help of BLI.

\section{LITERATURE}

Although BLI is an index for five years, while there is only one study in national literature (Turkish), there are almost fifteen studies in international literature. Kerenyi (2011: 518), explained detailed BLI and focused on data's related to Hungary. Boarini (2012), compared GDP with BLI and concluded apart from some countries whose GDP is high, their average BLI is also high. Kulesza and Jez (2012: 183), compared BLI with humanity development index, life satisfaction and GDP variations and discussed income inequality, reasons of income inequality and effects of income inequality to the life quality in Poland and in selected countries. Kasparian and Rolland (2012: 2223), discussed the definitions of BLI criteria's and aggregate of the values. They concluded that there is a hierarchy in evaluation of countries in BLI. Since the choice of weights in comparison among countries is insensitive.

Kettner and his friends (2012: 1), evaluated BLI for Austria and did a survey for eight hundred people. In that research, while health is the most important title, civic engagement and governance has less importance. Mizobuchi (2013: 987), said that all criteria in BLI are necessary for welfare, but mentioned that letting data's to users is a problem. He suggested composite indicator such as benefits of doubt (BOD) and data envelopment analysis. In conclusion, while BOD based composite indicator showed positive correlation with GDP and humanity development index, DEA based composite indicator showed negative correlation with GDP and humanity development index.

Jersey Statistic Unit (2013: 7,8), evaluated Jersey Island in its report according to BLI criteria's, and concluded that income 7.9, jobs 9.4, house 5.7, health status 8.5 , work and life balance 8.7, education 7.4, social connection 9.7, civic engagement and governance 0 , environment quality 6.3, security 9.5 and life satisfaction 9. Boarini and D'ercole (2013: 289), emphasized limitations of GDP in welfare measurement, and aimed solutions of these limitations with BLI. Akar (2014: 1), used BLI in her study and evaluated Turkey's status among OECD countries. She concluded that Turkey has the lowest life value in member countries. Nikolaev (2014: 61), examined economic freedom and BLI criteria's and found strong positive relations between them. In addition he concluded that changing in economic freedom effected both short and long term human development positively.

Hoskins and May (2014: 2), did welfare research using BLI indicators in Canada on the ten province among 2000-2013 years. Durand (2015: 4), discussed about criteria's in BLI and indicators of these criteria's pros and cons. Markovic, Zdravkovic, Mitrovic and Radojicic (2016: 1), evaluated BLI with I-distance approach. According to this approach, the lacks of subjective criteria's in BLI were identified. BLI and I- distance approach were compared according to importance levels and in high quality a common model was obtained. This model included six indicators such as personal gain, water quality, life satisfaction, household net adjusted disposable income, employment rate and the number of rooms per person.

\section{METHODOLOGY}

In this study, international welfare comparison is made using BLI with PPP based GDP per capita numbers in OECD and selected three countries in non OECD (Brazil, Russia and South Africa) and 2016 year data is used. The reasons are: Latvia and South Africa countries are added in 2016 data and 2016 year is the latest edition for BLI which is renewed itself year by year.

While BLI has eleven main criteria, these criteria's also included various indicators itself. Indicators of these criteria's are subjected separate scores. For example, while an indicator of income criteria of BLI which is household net adjusted disposable income is $13,471 \$$ in Turkey, an indicator of education criteria of BLI which is students skills are 462 scores in Turkey. BLI gives to the main criteria's among 0-10 scores and provided possibility to evaluate these eleven separate criteria in a standard way with the weighted average method. The aggregate of values is obtained with given scores among $0-10$ and they are divided to number of criteria. Thanks to it average BLI numbers of countries are determined. When $B L I$ is compared with GDP, reasons of being preferred PPP numbers are (TUiK, 2008: 2):

- One of the variables of BLI which is income criteria and its indicators incomes and fortunes of households are calculated by PPP based;

- PPP gives opportunity to comparison of real good and services eliminating the differences of price level among countries;

- In calculation of PPP, economic factors such as currency fluctuations, interest rates and capital flows are not taken into account;

- $\quad$ Rather than just National income, PPP based GDP per capita is more personal like BLI. 


\section{DETAILS OF BETTER LIFE INDEX (BLI)}

BLI is an index which was prepared by OECD on 24 May 2011 and applied considering not only according to economic welfare measurement GDP, but also according to social, cultural, environmental and political status. The President of France Sarkozy established the commission on the measurement of economic performance and social progress with as a president Joseph Stiglitz, as coordinators Amartya Sen and Jean-Paul Fitossi in 2008. Nearly thirty proposals were published by commission in September 2009 which is about how welfare measurement can be developed and this commission made up fundamentals of BLI (OECD, 2011: 15).

In that commission, to understand what the meaning of welfare is, necessity of usage of multidimensional definition is mentioned. Commission designed a welfare measurement which has eight items in the light of both academic research and concrete attempts in the World. (Stiglitz, Sen, \& Fitoussi, 2009: 14, 15):

a) Material living standards (income, consumption and wealth)

b) Health

c) Education

d) Personal activities including work

e) Political voice and governance

f) Social connections and relations

g) Environment (Present and future conditions)

h) Insecurity (economic and physical)

OECD got inspired from this commission and created BLI nearly after two years. Before adverting conceptual framework of this index, OECD and selected countries are shown below in table 1.

Table 1: Countries Which Applied BLI

\begin{tabular}{|l|l|l|l|l|}
\hline \multicolumn{5}{|c|}{ OECD MEMBERS COUNTRIES } \\
\hline Australia & Austria & Belgium & Canada & Chile \\
\hline Czech Republic & Denmark & Estonia & Finland & France \\
\hline Germany & Greece & Hungary & Iceland & Ireland \\
\hline Israel & Italy & Japan & Korea & Latvia \\
\hline Luxembourg & Mexico & Netherlands & New Zeland & Norway \\
\hline Poland & Portugal & Slovakia & Slovenia & Spain \\
\hline Sweden & Switzerland & Turkey & United Kingdom & United States \\
\hline \multicolumn{5}{|l|}{ SELECTED NON OECD COUNTRIES } \\
\hline Brazil & Russia & South Africa & \\
\hline
\end{tabular}

Source: (OECD Stat 2016)

While BLI is evaluated in OECD and in selected two countries Russia and Brazil first time in 2011, Latvia and South Africa countries joined in 2016.

In figure 1, Conceptual framework of BLI is located. This conceptual framework defined material standard of living, quality of life and sustainability in order to understand and to measure human welfare. While material standard of living and quality of life have a critical importance for those who lives before and today, It is very important that natural, human, economic and social capital protection for future generations (OECD, 2011: 18). 
Figure 1: Conceptual Framework of BLI

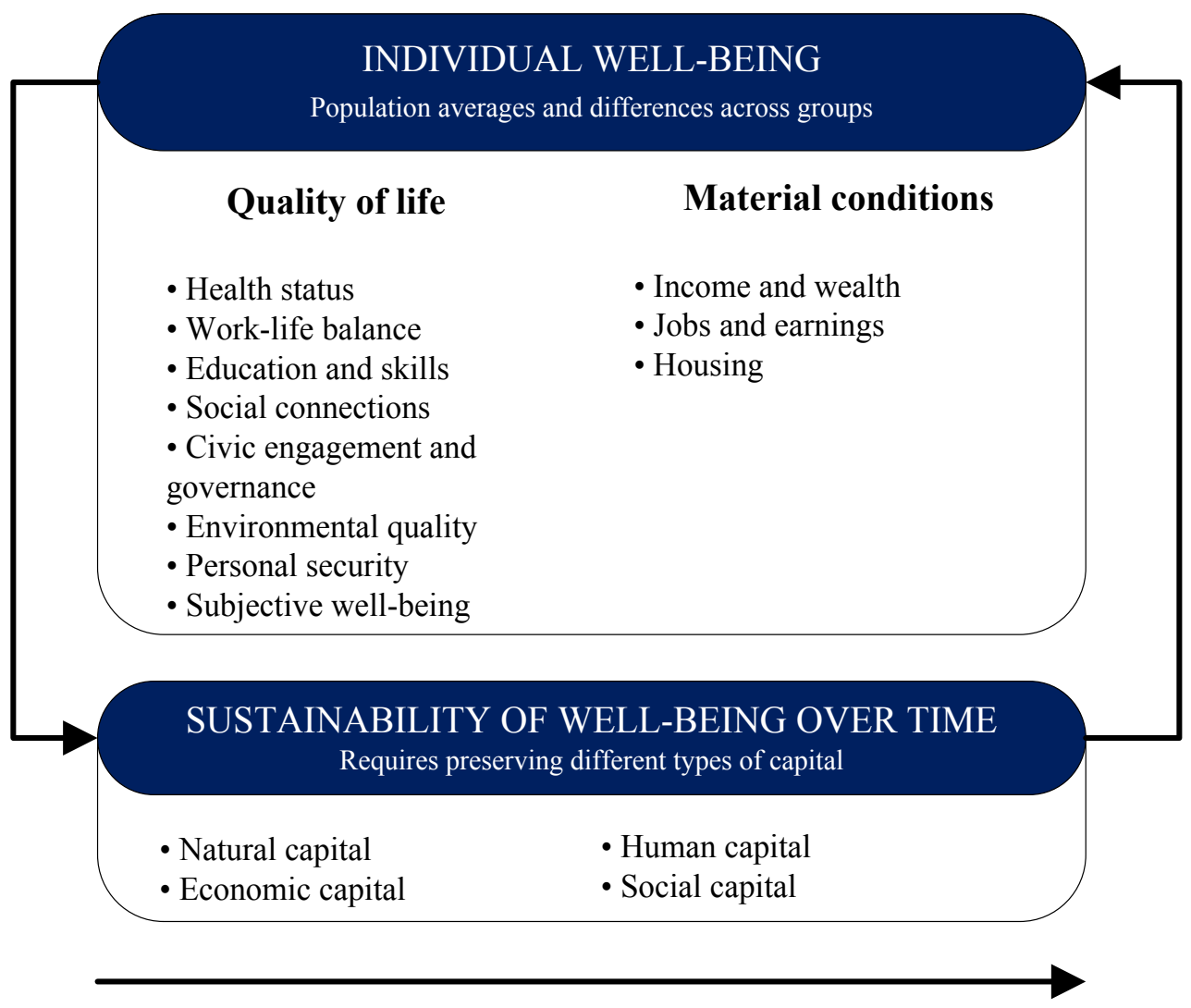

Source: OECD, 2011: 19

While according to $\operatorname{OECD}(2011: 37,265)$ and $\operatorname{OECD}$ (2013: 23), main criteria's of BLI and according to OECD Better Life Index (2016), indicators of criteria's of BLI are detailed explained, according to OECD Stat (2016), indicators of these criteria's are ranked as best and worst five countries based.

\subsection{Income and Wealth}

Income and wealth are basic components of personal welfare. While income meets needs of people and provides to achieve their targets which are so important in their life, wealth makes these choices continuously possible. Even though there are some values in life that can't be bought with money, both income and wealth develop individual's freedom in order to choose the life how they want to live. The income criterion of BLI includes two indicators in itself. (OECD, 2011: 37). These are household net adjusted disposable income and household net financial wealth.

Household net adjusted disposable income represents expenditures on goods and services. Household net adjusted disposable income includes wages and salaries, profits of the self-employed, property income, kind - cash social benefits and social transfers (OECD, 2016).

The highest five countries of household net adjusted disposable income: USA (41.071\$), Luxembourg (40.914\$), Switzerland (35.952\$), Norway (33.393\$) and Australia (33.138\$)

The lowest five countries of household net adjusted disposable income: South Africa (8.712\$), Brazil (11.487\$), Mexico (12.806\$), Turkey (13.471\$) and Latvia (13.655\$)

Household net financial wealth represents aggregate of financial values of households. It includes savings, monetary gold, currency and deposits, stocks, securities and loans (OECD, 2016).

The highest five countries of household net financial wealth: USA (163.268\$), Switzerland (120.265\$), Japan (92.818\$), Belgium (89.057\$) and New Zealand (81.271\$) 
The lowest five countries of household net financial wealth: Russia (3.687\$), Turkey (3.886\$), Brazil (7.566\$), Slovakia (8.896\$) and Latvia (9.837\$)

\subsection{Jobs and Earnings}

To have a job for individuals which matches their skills and aspirations and to obtain a sufficient gain are universal desires among the world (OECD, 2011: 57). Job quality of individuals increases not only their management on human resources but also their prestige in community (OECD, 2013: 23). Jobs and earnings criteria of BLI include four indicators in itself. These are employment rate, long term unemployment rate, average earnings and job security.

Employment rate represents between 15-64 ages working groups (OECD, 2016).

The highest five countries of employment rate: Iceland (\%82), Switzerland (\%80), Sweden (\%75), Norway (\%75), and Germany (\%74)

The lowest five countries of employment rate: South Africa (\%43), Greece (\%49), Turkey (\%50), Spain (\%57) and Italy (\%57)

For long term unemployment rate, actively seeking for a job but who has no jobs is defined as unemployed. Long term unemployment contains negative effects on welfare and eigenvalues and individuals can lose their skills in this period (OECD, 2016).

The highest five countries of long term unemployment rate: Greece $(\% 19,47)$, South Africa $(\% 14,37)$, Spain $(\% 12,92)$, Portugal $(\% 8,28)$ and Italy $(\% 7,79)$

The lowest five countries of long term unemployment rate: South Korea $(\% 0,01)$, Mexico $(\% 0,06)$, Norway $(\% 0,41)$, Israel $(\% 0,63)$ and Iceland $(\% 0,67)$

For average earnings, wages from employment and monetary benefits are important in job quality. Earnings represents main source of income for many households (OECD, 2016).

The highest five countries of average earnings: Luxembourg (61.511\$), USA (57.139\$), Switzerland (57.082\$), Iceland (56.789\$) and Ireland (53.286\$)

The lowest five countries of average earnings: South Africa (5.429\$), Brazil (10.229\$), Mexico (12.850\$), Turkey (15.992\$) and Estonia (21.020\$)

Job security shows that the length of unemployment with how much financial assistance the government can do (OECD, 2016).

The highest five countries of job security: Iceland (\%0.7), Norway (\%1.5), Switzerland (\%1.7), South Korea (\%2.1) and Luxembourg (\%2.1)

The lowest five countries of job security: Greece (\%32), Spain (\%26.6), South Africa (\%22,6), Italy (\%11.8) and Portugal (\%11.7)

\subsection{Housing Conditions}

Housing conditions is a main element of the material living standard of individuals and it is important in terms of meeting basic needs. Housing is also effective factor for health, personal welfare and social connections (OECD, 2011: 81). The housing criteria of BLI include three indicators in itself. These are rooms per person, dwellings with basic facilities and housing expenditure.

For rooms per person, when housing criteria is viewed, rooms per person are crucial in terms of to examine life conditions (OECD, 2016).

The highest five countries of rooms per person: Canada (2.5 rooms), USA (2.4 rooms), New Zealand (2.4 rooms), Australia (2.3 rooms) and Belgium ( 2.2 rooms)

The lowest five countries of rooms per person: South Africa (0.7 room), Brazil (0.9 room), Russia (0.9 room), Mexico (1 room) and Hungary, Poland, Slovakia, Turkey (1.1 rooms)

For dwellings with basic facilities, overcrowded house can leave negative effects on physical and mental health during the evolution of children (OECD, 2016).

The highest five countries of dwellings with basic facilities: USA (\%0.1), İreland (\%0.1), Spain (\%0.1), Luxembourg (\%0.1) and Canada (\%0.2) 
The lowest five countries of dwellings with basic facilities: South Africa (\%20.5), Latvia (\%14.7), Russia (\%14.4), Chile (\%9.4) and Turkey (\%7.6)

For housing expenditure, housing costs have a big portion in household budget and it represents the biggest expenditure for individuals and families (OECD, 2016).

The highest five countries of housing expenditure: Czech Republic (\%26), Latvia (\%26), Greece (\%26), Denmark (\%25) and Slovakia (\%25)

The lowest five countries of housing expenditure: Russia (\%11), South Korea (\%16), South Africa (\%18), Norway (\%18) and Chile (\%18)

\subsection{Health}

Being healthy is one of the most valuable direction of human life and this situation affects possibility of having a job, to obtain an adequate income and to join social activities as an active. (OECD, 2011: 103). Health criteria of BLI include two indicators. These are life expectancy and self-reported health.

For life expectancy, although life expectancy takes into account length of life of individuals, it is an indicator which is used the most widely in health criteria (OECD, 2016).

The highest five countries of life expectancy: Japan (83.4 age), Spain (83.2 age), Switzerland (82.9 age), Italy (82.8 age) and France (82.3 age)

The lowest five countries of life expectancy: South Africa (56.8 age), Russia (70.7 age), Latvia (74.1 age), Mexico (74.6 age) and Brazil (75 age)

For self-reported health, data's of this indicator is gathered asking "how is your health status?" (OECD, 2016).

The highest five countries of self-reported health: New Zealand (\%90), Canada (\%89), USA (\%88), Australia (\%85) and İreland (\%82)

The lowest five countries of self-reported health: South Korea (\%35), Japan (\%35), Russia (\%39), Portugal (\%46) and Latvia (\%50)

\subsection{Work - Life Balance}

Jobs, family ties and the ability to execute a combination of private life are important not only for welfare of household members but also for community. Because work-life balance provides enough time for individuals in order to socialize and to join community life (OECD, 2011: 123). Work-life balance criteria of BLI include two indicators in itself. These are working hours and time devoted to leisure and personal care.

Working hours indicator is one of the important directions of work-life balance for individuals in jobs. Long working hours may impair personal health, jeopardize safety and increase stress (OECD, 2016).

The highest five countries of working hours: Turkey (\%39.26), Mexico (\%28.28), South Korea (\%23.12), Japan (\%21.89) and South Africa (\%18.07)

The lowest five countries of working hours: Russia (\%0.18), Netherlands (\%0.44), Sweden (\%1.1), Denmark (\%2.21) and Latvia (\%2.45)

For time devoted to leisure and personal care, the amount of leisure time and quality are important for aggregate welfare of individuals and this situation also provides extra health advantages in terms of physical and mental (OECD, 2016).

The highest five countries of time devoted to leisure and personal care: France (16.36 hours), Spain (15.93 hours), Netherlands (15.9 hours), Denmark (15.87 hours) and Belgium (15.77 hours)

The lowest five countries of time devoted to leisure and personal care: Turkey (12.24 hours), Mexico (12.8 hours), Latvia (13.83 hours), İsrael (13.94 hours) and İceland (14.13 hours)

\subsection{Education and Skills}

Education and skills have a strong effect on individual's welfare. Education creates many opportunities for individuals and it has a huge importance for high economic growth, strong social cohesion and less crime rate (OECD, 2011:145). Education and skills criteria of BLI include three indicators in itself. These are years in education, educational attainment, student skills. 
For years in education, in a fast-changing knowledge economy, education is about learning skills for life. But how many years of school, college, or training will future generations expect to have (OECD, 2016)?

The highest five countries of years in education: Finland (19.7 years), Denmark (19.6 years), Iceland (19.6 years), Australia (19.2 years) and Sweden (19.1 years)

The lowest five countries of years in education: Mexico (14.4 years), Luxembourg (15.1 years), Brazil (15.6 years) Israel (15.9 years) and Russia (16.1 years)

For educational attainment, to have a well education increases both possibilities to find quality job and to earn adequate money. Educational attainment makes highly-educated individuals more attractive in the workforce so highly-educated individuals are less affected by unemployment trends (OECD, 2016).

The highest five countries of educational attainment: Russia (\%95), Japan (\%94), Czech Republic (\%93), Estonia (\%91) and Poland, Slovakia (\%91)

The lowest five countries of educational attainment: Mexico (\%34), Turkey (\%36), Portugal (\%43), Brazil (\%46) and Spain (\%57)

For student skills, OECD tests to measure 15 years old student's knowledge and skills with Programme for International Student Assessment (PISA) which is essential for full participation in modern societies, particularly in reading, mathematics and science $(O E C D, 2016)$.

The highest five countries of student skills: South Korea (542 average scores), Japan (540 average scores), Finland (529 average scores), Estonia (526 average scores) and Canada (522 average scores)

The lowest five countries of student skills: South Africa (384 average scores), Brazil (402 average scores), Mexico (417 average scores), Chile (436 average scores) and Turkey (462 average scores)

\subsection{Social Connections}

Social connections are valuable criteria for the development of the individual. Because many people report the funniest activity is which happens with others. Moreover social connections are important tool to reach the goals like finding job, supporting services when individuals need helps (OECD, 2013: 23). Social connections criteria of BLI include one indicator in itself. That is social support network.

For social support network, a strong social network or a strong community provides to reach not only opportunities like jobs, services and other material stuff but also provides emotional support in good and bad times (OECD, 2016).

The highest five countries of social support network: New Zealand (\%99), Denmark (\%96), Spain (\%96), İceland (\%96) and Australia, Ireland (\%95)

The lowest five countries of social support network: Mexico (\%75), South Korea (\%76), Hungary (\%82), Chile (\%82) and Greece (\%83)

\subsection{Civic Engagement and Governance}

Civic engagement gives an opportunity both announcing the voices of individuals and contributing the political function of society. Even civic engagement and governance is necessary for democracies, measure it is difficult (OECD, 2011: 187). Civic engagement and governance criteria of $\mathrm{BLI}$ include two indicators in itself. These are voter turnout and stakeholder engagement for developing regulations.

High voter turnout is a measurement of citizen's participation to the political process. Voter turnout is desired in democracies because voter turnout increases the chances of the individual to reflect the many wishes of the individual within the political system (OECD, 2016).

The highest five countries of voter turnout: Australia (\%93), Luxembourg (\%91), Belgium (\%89), Denmark (\%86) and Sweden (\%86)

The lowest five countries of voter turnout: Switzerland (\%48), Chile (\%49), Slovenia (\%52), Japan (\%53) and Poland (\%55)

Stakeholder engagement for developing regulations measures elements such as consultation methods, openness, transparency and feedback mechanisms. This indicator is calculated by taking simple average of the primary legislation and subordinate regulations (OECD, 2016).

The highest five countries of stakeholder engagement for developing regulations: Mexico (3.5 average scores), USA (3.2 average scores), Canada (3 average scores), United Kingdom (2.9 average scores) and Slovakia (2.9 average scores) 
The lowest five countries of stakeholder engagement for developing regulations: Ireland (0.8 average score), Russia (0.8 average score), Israel (0.9 average score), Hungary (1.2 average scores) and Portugal (1.2 average scores)

\subsection{Environmental Quality}

The effects of pollution, hazardous substances and noise on human health are so huge and human life is strongly affected from this situation (OECD, 2011: 211). The quality of environment where people lives and works is important for their own rights. At the same time environmental quality is crucial both for human health and to realize many activities such as raising children, social life etc. (OECD, 2013: 23). Environmental quality criteria of BLI include two indicators in itself. These are air pollution and water quality.

Open air pollution is an important environmental issue which affects to quality of human life directly. Although the national and international interventions and reductions in emissions, effects of urban air pollution on health are globally getting worse. The basic reasons of air pollution are transportation and using of small scale wood or coal (OECD, 2016).

The highest five countries of air pollution: South Korea (29 microgram), Israel (26 microgram), Belgium (19 microgram), Italy (18 microgram) and Chile (18 microgram)

The lowest five countries of air pollution: Australia (6 microgram), Norway (6 microgram), Finland (7 microgram), Sweden (7 microgram) and Iceland (7 microgram)

For water quality, access to clean water is a fundamental of human welfare. Being meeting the needs of clean water is a huge and growing problem in many parts of the World. Many people do not have adequate and quality water (OECD, 2016).

The highest five countries of water quality: Switzerland (\%97), Iceland (\%97), Norway (\%95), Denmark (\%95) and Sweden (\%95)

The lowest five countries of water quality: Russia (\%49), Turkey (\%63), Israel (\%65), Mexico (\%68) and South Africa, Greece (\%69)

\subsection{Personal Security}

Personal security is a serious component for human welfare. Although many factors affect personal safety, commit an offense is the most common of them. Commit an offense can cause loss of life and property, physical pain and traumatic stress in short and long time. To live in safety communities is valuable and necessary for human's welfare. Because insecurity feeling limits daily activities and functions of people (OECD, 2011: 239). Personal security criteria of BLI include two indicators in itself. These are feeling safe walking alone at night and homicide rate.

Feeling safe walking alone at night is an important issue for people because many working people or students have much more free time at night. Thus they want to feel themselves both safety and comfortable during walking alone at night.

The highest five countries of feeling safe walking alone at night: Norway (\%89.6), Switzerland (\%87.4), Finland (\%85.8), Denmark (\%85.2) and Slovenia (\%83.9)

The lowest five countries of feeling safe walking alone at night: Brazil (\%39.5), South Africa (\%39.8), Mexico (\%39.9), Chile (\%50.2) and Hungary (\%53.2)

Homicide rates do not give any clues about the typical security conditions just because they only represent most extreme crimes. But unlike other crimes, murders are usually reported to the police so it is more reliable measurement of countries safety level. The following data's are numbers in 100.000 persons (OECD, 2016).

The highest five countries of homicide rate: Brazil (26.7 numbers), Mexico (23.4 numbers), Russia (11.3 numbers), South Africa (9.6 numbers) and Latvia (6.1 numbers)

The lowest five countries of homicide rate: United Kingdom ( 0.2 number), Luxembourg ( 0.2 number), Denmark ( 0.3 number), iceland ( 0.3 number) and Japan ( 0.3 number)

\subsection{Personal Welfare (Life Satisfaction)}

Subjective well-being reflects the notion that how people experience a set of circumstances as important as for themselves and these people are the best judges of how their own lives are going. (OECD, 2011: 265). Personal welfare criteria of BLI include one indicator in itself. That is life satisfaction.

Life satisfaction measures how individuals evaluate their life rather than individuals current senses. Among 0-10 scores are given for evaluation of this indicator (OECD, 2016). 
The highest five countries of life satisfaction: Norway (7.6 average scores), Switzerland (7.6 average scores), Denmark (7.5 average scores), íceland ( 7.5 average scores) and Canada, Finland ( 7.4 average scores)

The lowest five countries of life satisfaction: South Africa (4.9 average scores), Portugal (5.1 average scores), Hungary (5.3 average scores), Turkey (5.5 average scores) and Estonia, Greece (5.6 average scores)

\section{THE EVALUATION OF OECD MEMBERS AND SELECTED COUNTRIES}

In order to observe and to see easier way of the fundamental aim of this study, three separate graphs are planned in this chapter. Numbers of PPP based GDP per capita of OECD members and selected countries are handled in first graph. Because of indicators of BLI criteria's are detailed explained in previous chapter, BLI criteria's of OECD members and selected countries are used as average BLI values based in second graph. Numbers of PPP based GDP per capita of OECD members and selected countries with average BLI values are compared on the same chart in third graph.

Graph 1: Numbers of PPP based GDP per capita of OECD Members and Selected (2016)

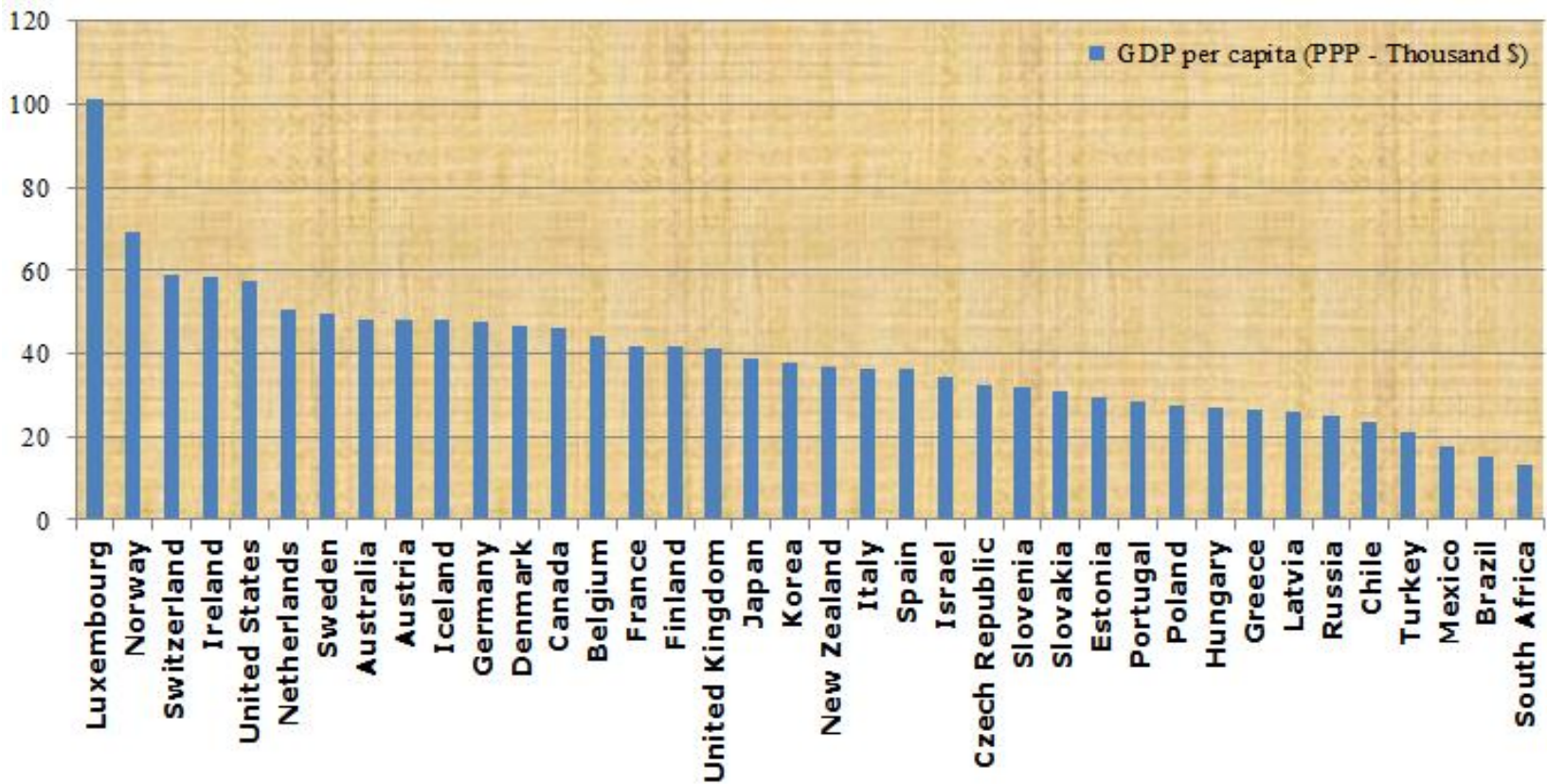

Source: IMF Word Economic Outlook Data Base, 2016

Numbers of PPP based GDP per capita of OECD members and selected countries are ranked for 2016 year in graph 1. According to first graph, while Luxembourg is located in first rank with 100,991\$, Norway is in second rank with 69,031\$, Switzerland is in third rank with 59,150\$, Ireland is in fourth rank with 58,372\$ and USA is located in fifth rank with $57,220 \$$. When we focused on the bottom of graph, while South Africa is located in last rank with $13,166 \$$, Brazil is in second rank from last with 15,048\$, Mexico is in third rank from last with 17,905\$, Turkey is in fourth rank from last with $21,198 \$$ and Chile is located in fifth rank from last with $23,803 \$$. 
Graph 2: The Average BLI of OECD Members and Selected (2016)

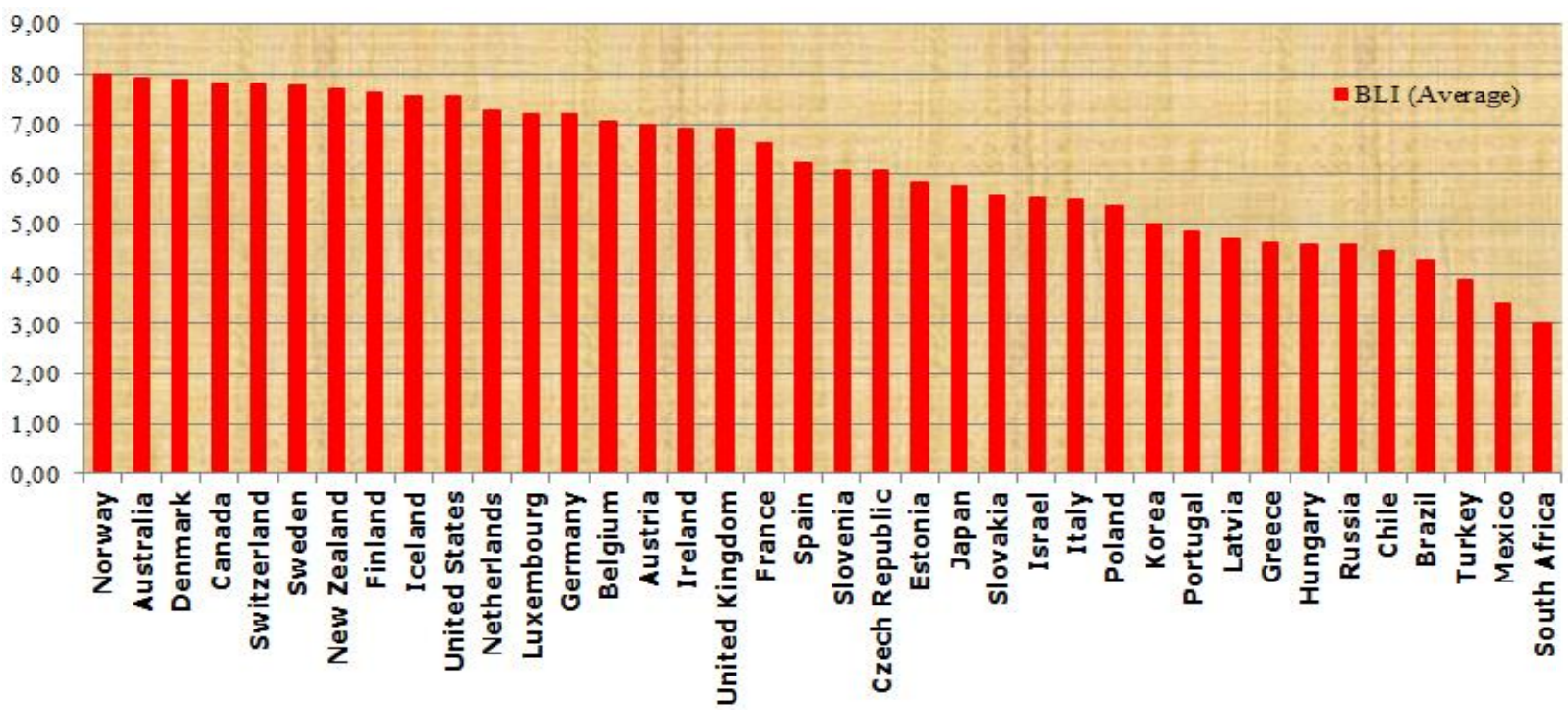

Source: It is created by Author using data from OECD Better Life Index, Countries, 2016

$\mathrm{BLI}$ gives an opportunity to make easier welfare analysis of eleven main criteria of twenty two indicators by giving scores among 0-10. Weighted average is used in this index and average BLI values are obtained while aggregate of calculated criteria's are divided number of criteria (11). Average BLI values of OECD members and selected countries are ranked in graph 2. According to this graph, while Norway is located in first rank with 8,01 average BLI, Australia is in second rank with 7,92 average BLI, Denmark is in third rank with 7,90 average BLI, Canada is in fourth rank with 7,83 average BLI and Switzerland is located in fifth rank with 7,82 average BLI. When we focused on the bottom of graph, While South Africa is located in last rank with 3 average BLI, Mexico is in second rank from last with 3,42 average BLI, Turkey is in third rank from last with 3,87 average BLI, Brazil is in fourth rank from last with 4,26 average BLI and Chile is located in fifth rank from last with 4,47 average BLI.

Graph 3: Comparison of PPP Based GDP Per Capita with BLI Averages in OECD Members and Selected (2016)

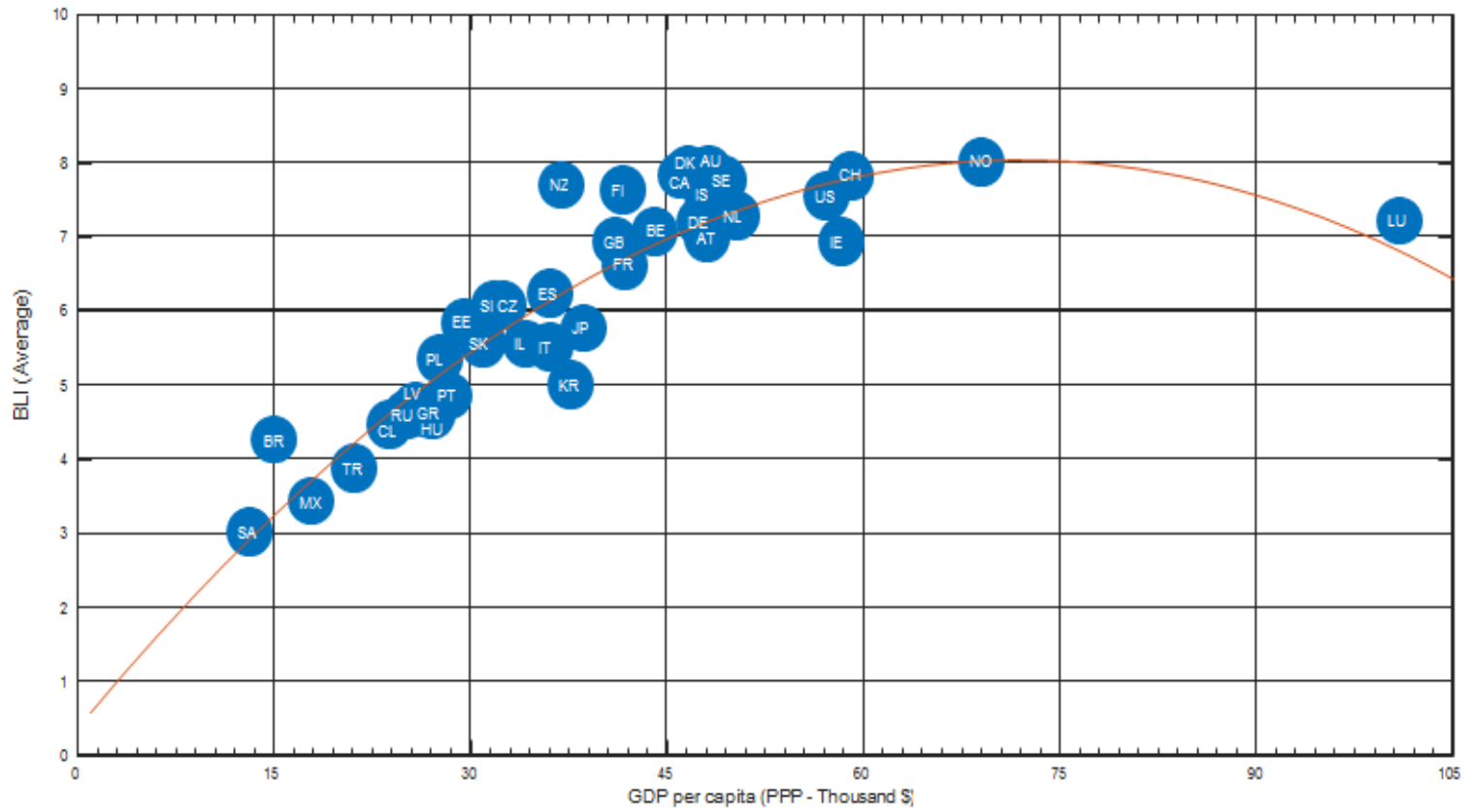

Source: It is created by Author using IMF Data Base and OECD Better Life Index countries data, 2016. 
Data's in graph 1 and graph 2 are collectively compared in graph 3. At a first glance, as if it seems a correct observation that countries which have high numbers in PPP based GDP per capita have also high average BLI values or countries which have low numbers in PPP based GDP per capita have also low average BLI values, when graph is detailed examined, conclusion is that there is no directly strong positive correlation as thought between these two parameters. Normally, at a first glance saying that Norway is located in second rank in GDP numbers rankings and in first rank in average BLI values rankings, also Switzerland is located in third rank in GDP numbers rankings and in fifth rank in average BLI values rankings or South Africa is located in last rank both in GDP numbers rankings and in average BLI values rankings, also Brazil is located in second rank from last in GDP numbers rankings and in fourth rank from last in average BLI values rankings and defending idea that national income affect welfare positively is possible. But in the light of the concrete data's, as a result of detailed examination it is seen that this opinion is not totally correct. For example, it is seen that although Luxembourg is located top rank in GDP numbers rankings with 100,991 \$, it is in twelfth rank with 7,21 scores in average BLI rankings. In addition, while Ireland is located in fourth rank with 58,372 in GDP numbers rankings, it is in sixteenth rank with 6,93 scores in average BLI values rankings, USA is located in fifth rank with 57,220\$ in GDP numbers rankings, it is in tenth rank with 7,55 scores in average BLI values rankings. Moreover, while Denmark is located in twelfth rank with $46,704 \$$ in GDP numbers rankings, it is in third rank with 7,90 scores in average BLI values rankings, while New Zealand is located in twentieth rank with 36,950 in GDP numbers rankings, it is in seventh rank with 7,70 scores in average BLI values rankings and Australia which is in eighth rank with 48,196\$ in GDP numbers rankings, it is in second rank with 7,92 scores in average BLI values rankings. These charts give concrete ideas that actually there is not a $\% 100$ positive relations between national income and welfare parameters.

Contrary to popular belief, poor relations of the national income and welfare parameters are connected two reasons by Boarini (2012). First reason is that, countries which possess better conditions in terms of welfare choose less working in order to provide a better life balance. This situation is interpreted like that although individuals have less income who decrease their working hours, they increase spending time with their family and friends. Second reason is that, countries which possess better conditions in terms of welfare have also better environmental quality owing to the lower economic production.

\section{CONCLUSION and SUGGESTIONS}

National income is really one of the most important tools in evaluating a country. But how accurate is it to match these criteria with direct welfare? The definition of welfare and in particular its measurement is a specific phenomenon that can not only explained by a national income criteria. Of course in order to survive life money and income are needed. But does this provide true serenity and happiness? In this study, International welfare comparison is made using the BLI with PPP based GDP per capita parameters. It is emphasized that how the bigness of national income numbers affect human welfare or better life.

At first glance, it can be asserted that there is a positive relation between GDP per capita and BLI parameters by saying that countries like Norway, Switzerland and Sweden are at the top both in national income per capita and BLI based rankings; or countries like South Africa, Mexico, Brazil, Turkey are at the bottom both in national income per capita and BLI based rankings. However, if there was a strong positive relation between GDP per capita and BLI; Luxembourg, which is by far the best in national income per capita ranking, wouldn't be placed rank number twelve in average BLI values ranking. Similarly, New Zealand, which is placed rank number twenty in national income per capita ranking among thirty eight countries, wouldn't be placed rank number seven in average BLI values ranking. These tangible examples are not limited to a few countries. For example, Ireland, which ranks fourth in GDP per capita rankings, ranks sixteenth in average BLI values rankings; Denmark, which ranks twelfth in the national income per capita, ranks third in terms of average BLI values rankings.

In conclusion, a country's high level of national income does not necessarily mean that it is at a level of contemporary civilization. If it is asked to evaluate a country in terms of welfare perspective, not just only monetary value of produced goods and services in that country shouldn't be taken into account but also factors such as education, justice, employment, security, environment and social connections should be taken into account from a wider perspective. Being considered of more than one dimension rather than one dimension in welfare measurement is very crucial for countries in terms of to see their shortcomings. Especially examination of New Zealand country is highly recommended for countries which have low GDP per capita numbers and low average BLI values. Because while New Zealand ranks twelfth in thirty eight countries in GDP per capita rankings, it ranks seventh in average BLI values rankings. After conclusion part, four suggestions will be mentioned which are related with BLI. The main reason of these suggestions is: Indicators of main criteria's of BLI can change year after year and it is known that these indicators are open to change.

Firstly, GINI coefficient which measures distribution of national income among households is thought to be added to the household net adjusted disposable income and household net financial wealth indicators of income and wealth criteria of BLI. If measurement of human welfare is planned, to take into consideration to the inequality of distribution of national 
income is more correct approach before individual income and wealth. Otherwise being realized income and wealth criteria which is not taken into account inequality of national income is deficient at least in terms of material life conditions.

Secondly, it is claimed by author that voter turnout indicator of civic engagement and governance criteria of BLI is insufficient in welfare measurement. For example according to the OECD Stat (2016), while Turkey is located in sixth rank in thirty eight countries in voter turnout rankings, it is located in third rank from last in average BLI values rankings. Another concrete example is that while Switzerland is located in last rank in thirty eight countries in voter turnout rankings, it is located in fifth rank in average BLI values rankings. May it be the same the vote of educated and paying taxes citizen with the vote of uneducated and evading taxes citizen? It is thought that instead of voter turnout indicator, bringing freedom of thought and expression indicator will be more suitable. Can the welfare be mentioned in the community where people can't express their emotions and ideas as they wish in respect and people who are not allowed to write and talk? Thus it is suggested that freedom of thought and expression indicator is more qualified rather than indicator of voter turnout for civic engagement and governance criteria of BLI.

Thirdly, it can be thought separate criteria for BLI in terms of transportation that "how often individuals use bicycle?" and "how often do countries support usage of bicycle?" or "what are the Incentive policies of governments for usage of bicycle?" (E.g. Special bicycle infrastructure, special bicycle roads, bridges, stops etc.). For example in Copenhagen which is the capital of Denmark 252,600 cars and 265,700 bikes made their way into the city every day over the last year. Copenhagen also spent 143 \$ million on bicycle infrastructure and bicycle bridges (Willage, 2016). According to Copenhagenize index which is about the most bike friendly city among 122 cities, Copenhagen ranked in the first place (The Copenhagenize Index, 2015). Therefore the most crucial reasons of these suggestions are: Usage of bicycle has both direct or indirect impressive potentials and positive externalities for environment, huge effect for human health and saving of fuel (about individual economy) which are one of the most important criteria's in BLI. And even all these applications require money, more important than money is vision. With this vision it also affects lives of future generations. In addition, It can be easily seen from graph 1, 2, 3 that although Denmark ranked in the twelfth place in terms of GDP, it ranked in the third place in terms of BLI.

Fourthly, as it is known that apart from OECD members, BLI is applied for Brazil, Russia and South Africa countries. In order to obtain more concrete and realistic results, BLI should include also countries like China, India or more African countries. Why China and India should take place in BLI? The main reasons are; China and India have not only huge importance for world economy, but also these two countries make up for nearly \% 35 of World population. In addition, life quality of citizens of China and India countries is questioned especially among developing countries. Why more African countries should take place in BLI? The main reason is that problems of objective criteria's of BLI such as housing, environment quality, health, safety etc. are more evident in Africa continent rather than Europe and America. If more African countries are examined by using BLI via OECD, this examination can provide more objective welfare evaluation among continents.

\section{REFERENCES}

Akar, S. (2014). Türkiye'de Daha İyi Yaşam Endeksi: OECD Ülkeleri İle Karşılaştırma. Journal of Life Economics, pp. 1-12.

Barraso, J. M., Pöttering, H.-G., Almunia, J., \& Berès, P. (2007). Beyond GDP. Measuring progress, true wealth and well-being. Brussels: European Comission, European Parliament, Club of Rome, WWF, OECD.

Boarini, R. (2012). Well-being and GDP: why we need them both. http://www.oecdbetterlifeindex.org/blog/well-being-and-gdp.htm.

Boarini, R., \& D'ercole, M. M. (2013). Going beyond GDP: An OECD Perspective. Journal of Applied Public Economics,vol. 34(3), pp. $289-314$.

CASSE. (2009). GDP and Indicators of Economic Wellbeing. Briefing Papers.

Chaves, E. J. (2003). Toward a Center-Periphery Model of Global Accounting. Globalization: Critical Perspectives. New York: Nova Scince Publishers.

Conceição, P., \& Bandura, R. (2008). Measuring Subjective Wellbeing: A Summary Review of the Literature. UNDP, pp. 1-24.

Costanza, R., Hart, M., Posner, S., \& Talberth, J. (2009). Beyond GDP: The Need for New Measures of Progress. The Pardee Papers no.4, pp. 1-37.

Coyle, D. (2014). Is GDP still useful? http://www.oecdbetterlifeindex.org/blog/is-gdp-still-useful.htm.

Durand, M. (2015). The OECD Better Life Initiative: How's Life? and the Measurement of Well-Being. The review of income and wealth, vol. 61(1), pp. 4-17.

Economist, T. (2016). Why GDP is a poor measure of progress. http://www.economist.com/blogs/economist-explains/2016/05/economistexplains-1. 
Hoskins, P., \& May, D. (2014). OECD's Better Life Index For Canada and Provinces: Challenges and Results. https://www.mun.ca/care/topics/BLI_paper_Final_2014.pdf.

IMF. (2016). World Economic and Financial Surveys World Economic Outlook Database. http://www.imf.org/external/pubs/ft/weo/2016/01/weodata/index.aspx.

States of Jersey Statistics Unit. (2013). Jersey's Better Life Index 2013. https://www.gov.je/SiteCollectionDocuments/Government\%20and\%20administration/R\%20JerseysBetterLifelndex\%2020130322\%20SU.p df.

Kasparian, J., \& Rolland, A. (2012). OECD's Better Life Index: Can Any Country Be Well Ranked? Research Article, Journal of Applied Statistics, vol. 39(10), pp. 2223-2230.

Kendall-Bilicki, S. (2012). Beyond GDP: Better Ways to Measure Better Lives. http://www.oecdbetterlifeindex.org/blog/the-better-lifeindex.htm.

Kerényi, Á. (2011). The Better Life Index of the Organisation for Economic Co-operation and Development. Public Finance Quarterly, vol. 56(4), pp. 518-538.

Kettner, C., Köberl, K., Mayrhuber, C., Karmasin, S., Steininger, N., Haas, S., et al. (2012). Beyond GDP Measuring well-being and quality of life with the OECD Better Life Index in selected countries based on Austrian preferences. http://www.bmwfw.gv.at/Wirtschaftspolitik/Standortpolitik/Documents/Executive\%20Summary\%20in\%20EN.pdf.

Kulesza, M., \& Ucieklak-Jez, P. (2012). Poland and Selected Countries in the Light of OECD's Better Life Index. http://dlibra.bg.ajd.czest.pl:8080/Content/1114/Pragmata_6-183.pdf.

Kuznets, Simon. (1934). National Income, 1929-1932. 73rd US Congress, 2nd session, Senate document (pp. 1-12). New York: National Bureau of Economic Research.

Markovic, M., Zdravkovic, S., Mitrovic, M., \& Radojicic, A. (2016). An Iterative Multivariate Post Hoc I-Distance Approach in Evaluating OECD Better Life Index. Social Indicators Research,vol. 126(1), pp. 1-19.

McGillivray, M., \& Clarke, M. (2006). Human well-being: Concepts and measures. Understanding Human Well - being. United Nations University Press.

Mizobuchi, H. (2013). Measuring World Better Life Frontier: A Composite Indicator For OECD Better Life Index. Springer Science Business, pp. 987-1007.

Nikolaev, B. (2014). Economic Freedom and Quality of Life: Evidence from the OECD's Your Better Life Index. The Journal of Private Enterprise, vol. 29(3), pp. 61-96.

OECD. (2011). How's Life? 2011 Measuring Well-Being. Paris: Oecd Publishing.

OECD. (2013). How's Life? 2013 Measuring Well-Being. Paris: OECD Publishing.

OECD. (2016). Better Life Index - Edition 2016. http://stats.oecd.org/.

OECD. (2016). OECD Better Life Index. http://www.oecdbetterlifeindex.org/topics/.

Stiglitz, J., Sen, A., \& Fitoussi, J.-P. (2009). Report by the Commission on the Measurement of Economic Performance and Social Progress. http://www.insee.fr/fr/publications-et-services/dossiers_web/stiglitz/doc-commission/RAPPORT_anglais.pdf.

The Copenhagenize Index (2015). http://copenhagenize.eu/index/about.html.

Thomson, S. (2016). GDP a poor measure of progress, say Davos economists. https://www.weforum.org/agenda/2016/01/gdp/.

TUik. (2008). Satınalma Gücü Paritesi Sorularla Resmi İstatistikler Serisi - 4. Ankara: Türkiye İstatistik Kurumu.

Willage, A. (2016). More bikes than cars: this is the world's most bike-friendly city. https://www.weforum.org/agenda/2016/12/this-citycentre-now-has-more-bikes-than-cars/. 